Portland State University

PDXScholar

$10-2011$

\title{
Twitter and Facebook for User Collection Requests
}

Joan Petit

Portland State University, jpetit@pdx.edu

Follow this and additional works at: https://pdxscholar.library.pdx.edu/ulib_fac

Part of the Library and Information Science Commons

Let us know how access to this document benefits you.

\section{Citation Details}

Petit, Joan, "Twitter and Facebook for User Collection Requests" (2011). Library Faculty Publications and Presentations. Paper 103. http://archives.pdx.edu/ds/psu/9806

This Post-Print is brought to you for free and open access. It has been accepted for inclusion in Library Faculty Publications and Presentations by an authorized administrator of PDXScholar. Please contact us if we can make this document more accessible: pdxscholar@pdx.edu. 


\title{
Techcast
}

\section{Twitter and Facebook for User Collection Requests}

\author{
JOAN PETIT \\ Portland State University, Portland, Oregon
}

Libraries are offering more services through social media Web sites like Twitter and Facebook, and this presence online is encouraging more conversation between libraries and patrons, including collection development requests. A review of popular Twitter and Facebook library profiles reveals the most successful accounts to be those where the library actively engages its users online. Through these media, libraries can have direct, immediate conversations with patrons that result in patron-initiated material requests.

Keywords: Twitter, Facebook, social media, social networking, Web 2.0, collection development

Address correspondence to Joan Petit, Humanities and Social Sciences Librarian, Portland State University Library, P.O. Box 1151, Portland OR 97207-1511. E-mail: jpetit@pdx.edu. Twitter: @joanpdx

As the user-centered, interactive Web sees explosive growth, libraries are expanding their online presence beyond the library Web site to social networking sites like Facebook, Twitter, blogs, and more. Pinning down the precise number of libraries using Facebook and Twitter is challenging, in part because the numbers change so quickly. Lindy Brown started tracking libraries with Twitter accounts for a library school assignment in 2008 
(http://lis5313.ci.fsu.edu/wiki/index.php/Twittering_Libraries), when she found fewer than 100. Her spreadsheet, which she still maintains, lists 865 accounts held by libraries or libraryaffiliated groups on Twitter as of April 2011. OCLC reports approximately 11\% of larger public libraries have a Facebook Page, and that, as of January 2011, Facebook has over 15,700 URLs that include the word "library" (Brown 2011, OCLC 2010).

These sites allow conversations between librarians and patrons, and some libraries have begun to use these tools for reference and public service outreach. Now patrons are talking back to the library, including with requests for materials to be added to libraries' collections. This TechCast addresses these questions: How do library patrons use social media to request books and other materials from their libraries? What are the advantages and disadvantages of using social media for patron-initiated collection development? And how can libraries best use social media to solicit patron feedback and collection requests?

Informal conversations with other librarians involved in social media confirm that patrons are requesting materials from the library through Facebook and Twitter. On Facebook, this typically takes the form of a comment made on the wall of a library's official Facebook Page by a Facebook user who has chosen to Like and follow that Page (for example, see the Facebook Page of Multnomah County Library in Portland, Oregon here: https://www.facebook.com/multcolib). On Twitter, anyone with an account can direct a comment or question to another user by adding @ (the "at” symbol) in front of the user's Twitter identity (see Multnomah County Library’s Twitter page here: http://twitter.com/\#!/MultCoLib).

There are real advantages for libraries using social media. First, cost and accessibility: any library can create a Twitter or Facebook account for free, and the technology is easy to use, especially for librarians already familiar with these services. Next, many people already follow 
and interact with their favorite organizations and institutions via Facebook and Twitter, which seems to create a sense of familiarity with users that they may not feel using the library's Web site. For example, the corporation Coca-Cola has an astoundingly popular presence in social media, with over 26 million Facebook fans (https://www.facebook.com/cocacola) and over 270,000 Twitter followers (http://twitter.com/\#!/CocaCola). The sportswear company Nike has garnered over 4 million followers on Facebook, where their posts often generate over 1000 “likes” and hundreds of comments; on Twitter, Nike Soccer has over 100,000 followers (http://twitter.com/\#!/nikesoccer). The Library of Congress, one of the more popular libraries active on social media, has over 43,000 followers on Facebook (https://www.facebook.com/libraryofcongress) and over 210,000 on Twitter (http://twitter.com/\#!/librarycongress). In April 2011, the social-media oriented New York Public Library began recruiting volunteers to help transcribe 10,000 digitized menus from its historical restaurant menus collections, to make the materials fully searchable. The library promoted the project solely through Facebook, Twitter, and the Web site Metafilter. As of three months later, thousands of volunteers had already transcribed more than 450,000 dishes from over 8,500 menus (Mainland 2011). The New York Public Library menu project thus has become an outstanding example of how a library can use social media first to promote a collection and then also to build and improve that very same collection. For information on the project, see http://menus.nypl.org.

\section{Grr... not happy with AUC's ILL...}

3:33 AM Aug 19th from Tweetie

FIGURE 1 In 2009, when I worked at the American University in Cairo Library, I followed an AUC graduate student via my personal account on Twitter. One day, I noticed this tweet, where he complained about my library's interlibrary loan service. I replied and learned that he had requested too many chapters from one particular book so ILL was unable to fulfill his request. As the librarian for the subject area, I then ordered the book. 
Many library patrons already are on Twitter and Facebook, and we should be too. Indeed, and perhaps most importantly, library patrons may expect their libraries to have a social media presence now that Twitter, Facebook, and other services are so ubiquitous. Thus, by having an active social media presence, we are fulfilling the expectations of some users, and finding users we might not connect with elsewhere.

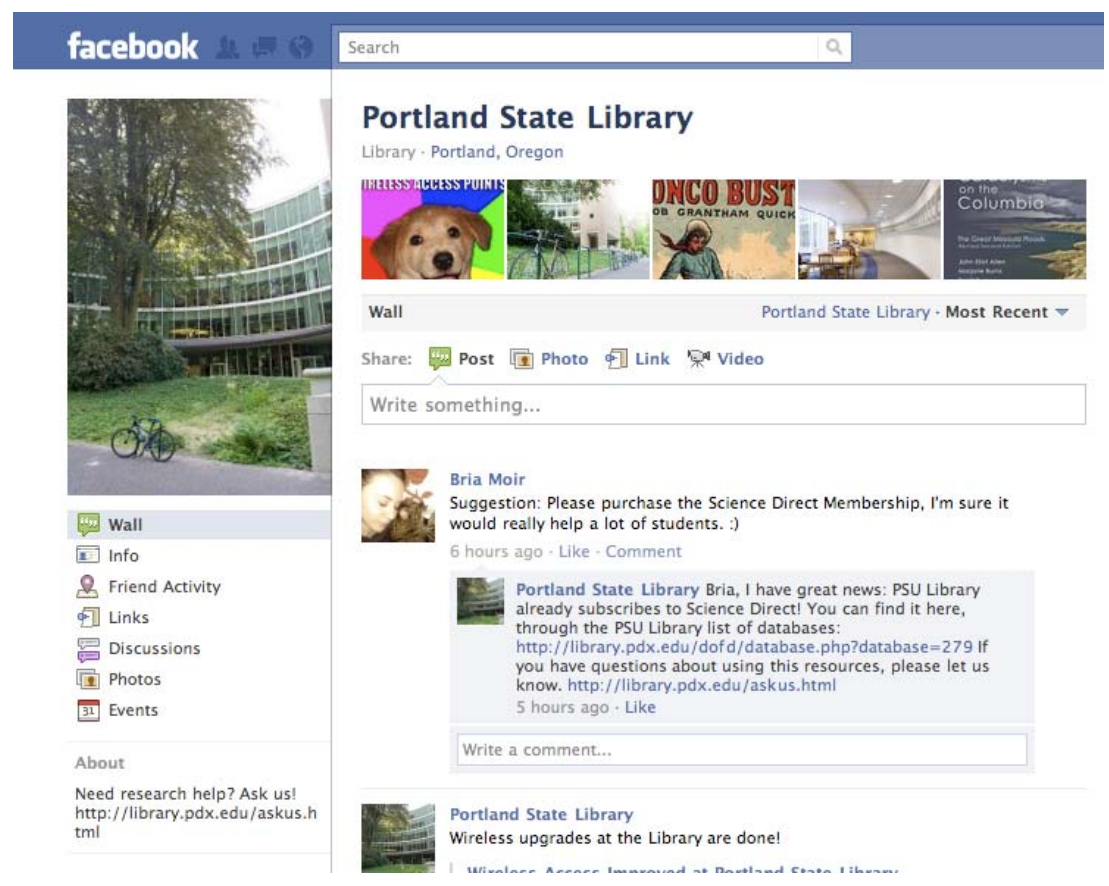

FIGURE 2 I created my library's Facebook page in January 2011, and we have a small but growing set of followers. This screenshot of the library's Facebook Page shows a collection request from a student for a database subscription, though one that we already have. Sometimes collection requests on Facebook can actually be reference transactions.

The most successful social media accounts tend to be those where the libraries actively engage with people, by responding to them or mentioning them. However, the creation of a Facebook Page or Twitter account does not guarantee success. Not every library devotes resources to its social media presence, and the Web is littered with dozens of abandoned or lightly used Pages and accounts that linger without updates or followers. The nature of social networking makes it difficult to develop a formal program around this service. To have a successful presence in social media, libraries must invest considerable personnel time. The best 
people for this are those that understand the culture of Twitter and Facebook and post appropriate, relevant content to each service. The immediacy of the interactive Web means people often expect a fast response, and libraries should respond fairly quickly to comments made to them via social media.

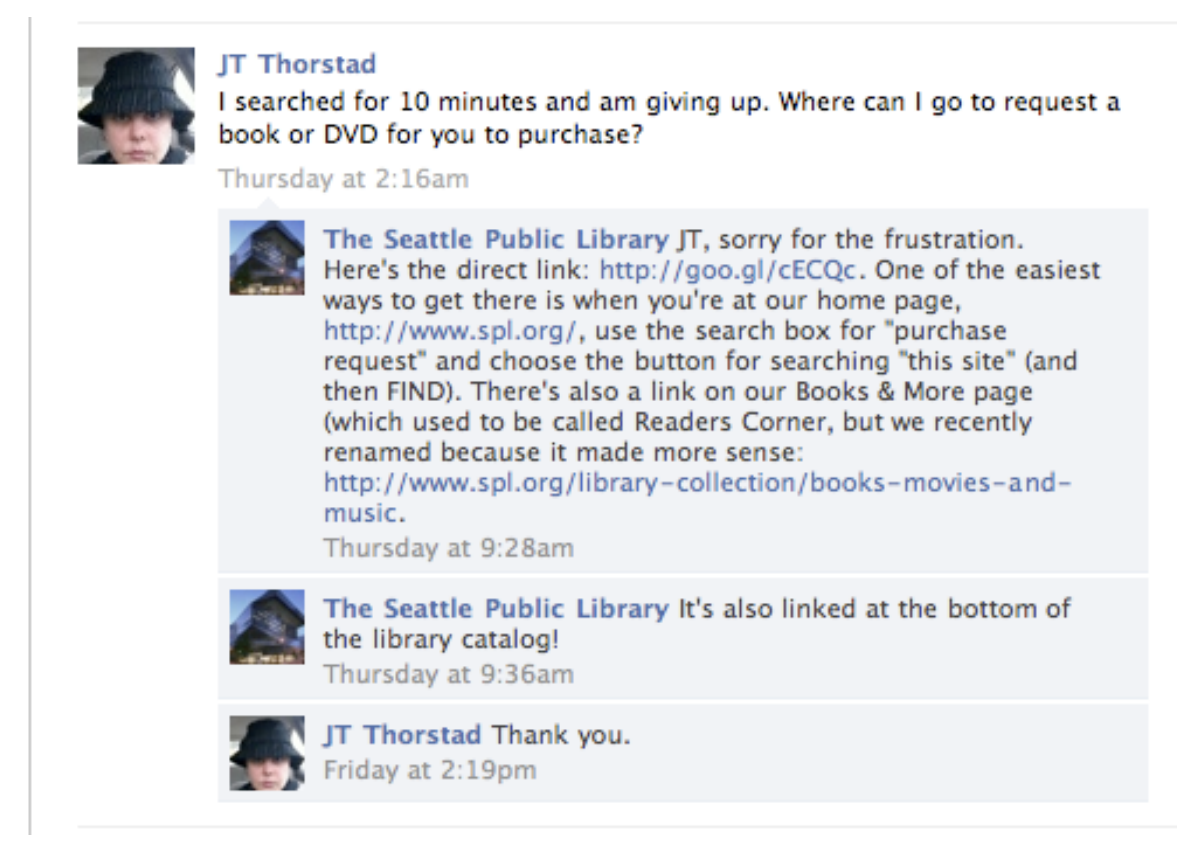

FIGURE 3 This Seattle Public Library patron could not locate the material request form on the library's website, so she directed this question to the library via Facebook.

Libraries without social media accounts who are interested in going online are encouraged to consider the issue carefully. First, examine a range of social media accounts of similar libraries, and evaluate what makes them successful (or not successful). Consider how many fans or followers the library has; more is not always better, but more followers often results in more conversation and interaction. Also consider how often the library updates its status. Do people respond to the library's posts? Do users direct comments to or ask questions of the library? How often are patrons leaving comments on their wall or replying to them? On Twitter, how often are the library's tweets re-tweeted? How often do users mention the library? 
Kevin KK Chan Wish there were more Chinese (simplified) books and

DVDs at our Multnomah Libraries. Some up-to-date textbooks for

learning Mandarin Chinese would be great too.

April 10 at 8:19am - Comment - Like - Report

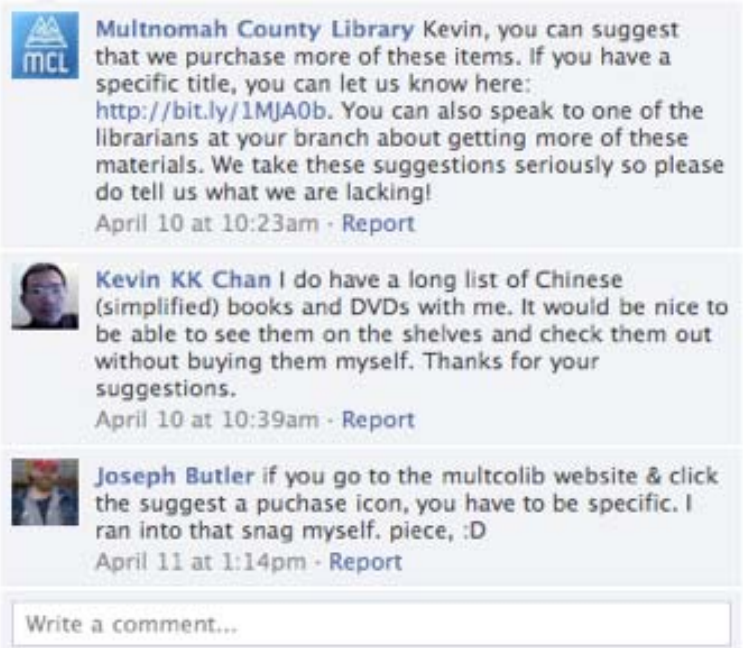

FIGURE 4 This Multnomah County Library patron directed a general material request to the library’s Facebook page. Note that the library addressed his question about two hours later, which is a great response time.

Next, the library needs to ask its community and itself the following questions: What social media do our users currently use? What are our users already saying about us via social media? Do we have time and people to dedicate to this? Are we committed to making this technology work in our library? What is our plan for promoting our presence online?

If a library decides to pursue a presence in social media, then, once established, these accounts can be used to encourage and even solicit collection requests. We can directly ask our users, “What books or materials would you like to see that we don’t have?” or "What book did you want to find, but couldn’t find, in our library?” We can also find out what our users are already saying on Twitter-by following their feeds_-and see if they have unmet needs we had not previously considered. But, any presence must be part of a larger program of marketing, reference, and event promotion. The library is all of these things to our users, and our presence in social media must reflect our multi-faceted roles. 
It can be challenging to develop a program through social networking as it takes time for any new social media presence to catch the attention of its core constituents. Even with a successful social media presence, there is no guarantee patrons will address collection requests through this forum. Still, our presence on social media can empower our users to interact in a spontaneous, direct, and immediate way with their libraries, and this, can help us build stronger collections.

To learn best practices for libraries using Facebook and Twitter, I recommend the following:

Solomon, Laura. 2011. Doing social media so it matters: A librarian’s guide. Chicago: American Library Association.

Gagliardi, Kelsey. 2011. How to use social media to engage students. https://docs.google.com/document/d/1dvxlOmQUm9j20r8tuf1oRMlfq-1P5DszvJC0u9Agug/edit?hl=en\#.

\section{REFERENCES}

Brown, Lindy. 2011. Twitter \& libraries, revisited. Circulation. http://lindybrown.com/blog/2011/04/twitter-libraries-revisited-excel-file/. Accessed May 15, 2011.

Mainland, Alexis. 2011. The library hands out menus to thousands of volunteers. New York Times: Diner’s Journal. http://dinersjournal.blogs.nytimes.com/2011/04/26/the-libraryhands-out-menus-to-thousands-of-volunteers/.

OCLC. 2010. Perceptions of libraries, 2010: Context and community. http://www.oclc.org/reports/2010perceptions/2010perceptions_all.pdf. Accessed May 15, 2011. 